\title{
A Rare Presentation of Germ Cell Neoplasia: Persistant Müllerian Duct Syndrome
}

\section{Germ Hücreli Neoplazinin Nadir Bir Prezentasyonu: Persistan Müllerian Kanal Sendromu}

\author{
Alp Tuna Beksaç MD1', Muhammet İrfan Dönmez MD¹, Çisel Aydın MD², Dilek Ertoy Baydar MD², Mustafa Sertaç Yazıcı MD, \\ Ali Ergen MD', Bülent Akdoğan MD'1 \\ 'Hacettepe University Faculty of Medicine, Department of Urology, Ankara, Turkey \\ 2Hacettepe University Faculty of Medicine, Department of Pathology, Ankara, Turkey
}

\begin{abstract}
Persistent Müllerian duct syndrome is a rare form of pseudohermaphroditism. This article is made of two case reports showing malignant transformation. The first case was a 36-year-old male who presented with infertility. Unilateral inguinal mass and undescended testis were found on physical examination. The inguinal ultrasonography reported an inguinal mass on the same side while testicular tumor markers were within normal range. After surgical excision, pathologic examination revealed that the inguinal mass was uterus and intratubular germ cell neoplasm was present in the testis tissue. The second case was a 31-year-old male with $18 \mathrm{~cm}$ intraabdominal mass which was noticed during umbilical hernia repair. Physical examination revealed bilateral undescended testes with increased human chorionic gonadotropin levels. Preoperative abdominal imaging revealed a uterus posteriorly of the mass. Excision of the mass and retroperitoneal lymph node dissection were performed after neoadjuvant chemotherapy. Pathology results revealed seminoma of the testis.
\end{abstract}

Keywords: Persistent Müllerian duct syndrome, seminoma, germ cell neoplasia
Öz

Persistan Müllerian kanal sendromu, yalancı hermafroditizmin nadir bir formudur. Bu yazıda malign transformasyon gösteren iki olgunun sunumu yapılmaktadır. İlk olgu infertilite sebebiyle başvuran 36 yaşında bir erkek hasta olup fizik muayenesinde tek taraflı inguinal kitle ve inmemiş testis saptanmıştır. Tümör belirteçleri normal olan hastanın inguinal ultrasonografi sonucu aynı tarafta inguinal kitle şeklinde raporlanmıştır. Cerrahi eksizyon sonrası patolojik incelemede inguinal kitlenin uterus olduğu ve testis dokusunda intratübüler germ hücreli neoplazi mevcut olduğu bulunmuştur. İkinci hasta ise umbilikal herni onarımı esnasında $18 \mathrm{~cm}$ 'lik intraabdominal kitle fark edilen ve yapılan fizik muayenesinde bilateral inmemiş testis saptanan 31 yaşında bir erkek hastadır. Hastanın laboratuvar değerlendirmesinde insan koryonik gonadotropini değeri artmış olup yapılan abdominal görüntülemesinde kitlenin posteriorunda yerleşmiş uterus izlenmiştir. Neoadjuvan kemoterapi sonrası kitle eksizyonu ve retroperitoneal lenf nodu diseksiyonu yapılmıştır. Patoloji sonucu seminom olarak bulunmuştur.

Anahtar Kelimeler: Persistan Müllerian kanal sendromu, seminom, germ hücreli neoplazi

\section{Introduction}

Persistent Müllerian duct syndrome (PMDS) is defined as the presence of Müllerian remnants in a phenotypically and karyotypically male (1). PMDS is caused either by the lack of anti-Müllerian hormone, receptor insensitivity or a defect in the timing of the release of Müllerian inhibiting factor (MIF). PMDS is regarded as a form of pseudohermaphroditism due to presence of uterus and is shown to be inherited autosomal recessively (2). Although it is predominantly seen in pediatric age group presenting as undescended testis with or without inguinal hernia, it might be presented as an inguinal or intraabdominal mass in adulthood (3). Herein we report 2 cases of PMDS with review of the literature.

\section{Case Presentations}

\section{Case 1}

A 36-year-old male was evaluated in our infertility clinic. The patient had history of bilateral orchidopexy when he was 4 years old. His repetitive spermogram results were consistent with azospermia. Chromosomal analysis was $46, \mathrm{XY}$. Upon physical examination right inguinal mass and left undescended testis was detected. Scrotal ultrasonography revealed that the right testicle was in right hemiscrotum with dysmorphic appearance. The mass located in the right inguinal canal was $75 \times 32 \mathrm{~mm}$, heterogenous, cavitary in the centre and hypervascularized. Left testicle could not be identified by ultrasound. Serum alpha fetoprotein and beta human chorionic gonadotropin ( $\beta$-hCG) 
levels were within normal range. Right inguinal exploration and complete excision of the mass was performed.

\section{Pathology}

Macroscopic examination revealed a well-formed $5 \mathrm{~cm}$ uterus, two fallopian tubes and a $3 \times 3 \times 2 \mathrm{~cm}$ testis (Figure 1). A section through the uterus revealed a patent uterine cavity, and short blind ending cervical canal. Microscopically, endometrium was inactive overlying unremarkable myometrium (Figure 2a). Testis contained small seminiferous tubules, some of which contained germ cells with deficient spematogenetic activity. These germ cells looked atypical with large and hyperchromatic nuclei

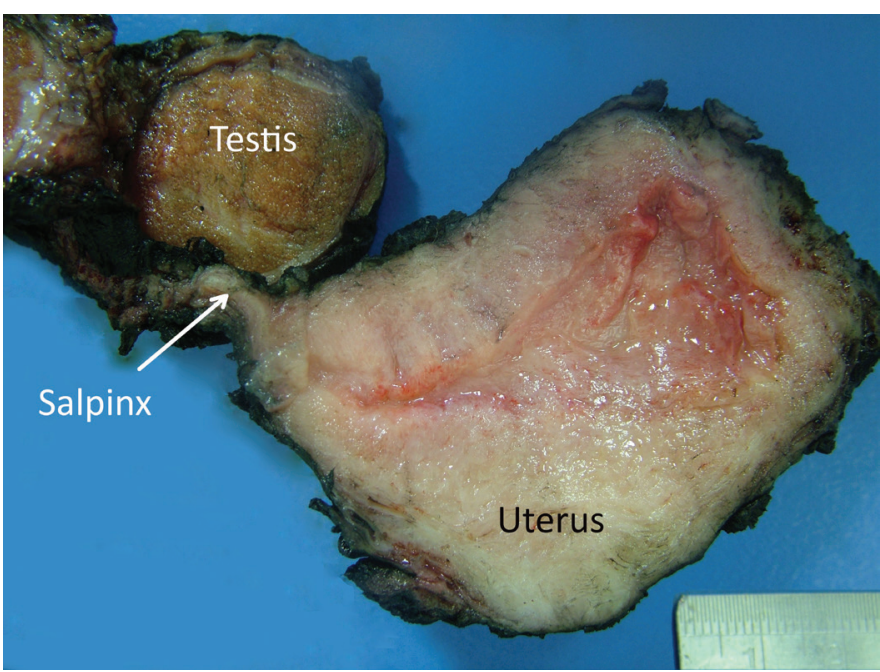

Figure 1. Case 1. Small testis connected to uterus by a salpinx

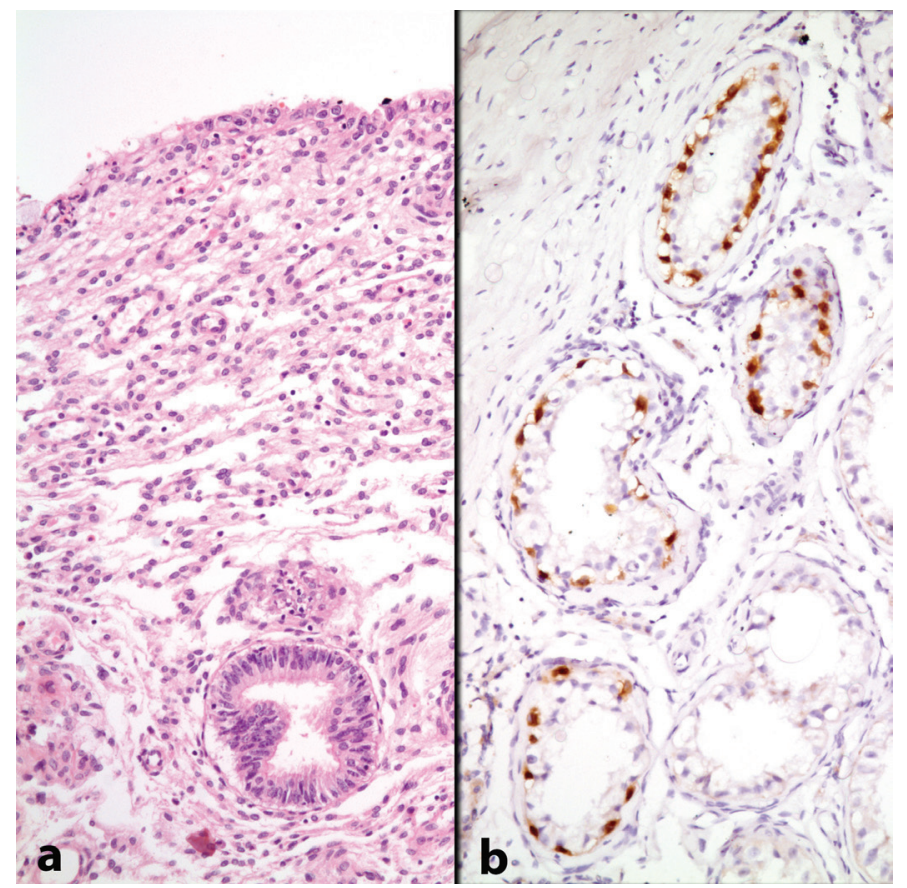

Figure 2. Case 1.a) A section from endometrium (hematoxylin and eosin $\times 200)$, b) Neoplastic germ cell in the seminiferous tubules revealing nuclear OCT3/4 expression (immunohistochemistry, anti-OCT3/4 antibody $\times 200$ ) leading to the diagnosis of intratubular germ cell neoplasia. This conclusion was confirmed via immunohistochemistry that showed OCT3/4 expression in the neoplastic germ cell nuclei (Figure 2b). No invasive tumor was identified.

Follow-up imaging at six and twelve months including abdominal magnetic resonance imaging and computed tomography (CT) of the thorax were unremarkable with normal tumor markers.

\section{Case 2}

A 31-year-old male patient was referred to our hospital due to incidentally detected intraabdominal lesion. Patient was asymptomatic until he underwent surgery for umbilical hernia where the general surgeon noted a mass in the abdominal cavity. Abdominal CT revealed an $18 \times 6 \mathrm{~cm}$ pelvic tumor lying superior to bladder and a uterus behind the bladder. Since he had untreated bilateral undescended testes, the mass was thought to be a testicular neoplasm. Serum $\beta$-hCG level was elevated $(551 \mathrm{mlU} / \mathrm{mL})$. Followed by tru-cut biopsy in which the findings were consistent with classic type seminoma. The patient was given a 3 course of bleomycin-etoposidecisplatin chemotherapy. $\beta$-hCG level decreased to normal. He was found to be azospermic with karyotype of $46, X Y$ and he had normal testosterone levels. Per-operatively, inner genitalia was phenotypically female; male organs were unable to be visualized. Uterus, together with pelvic tumor were removed and a template retroperitoneal lymph node dissection was achieved.

\section{Pathology}

Specimen consisted of $19 \times 6 \times 3 \mathrm{~cm}$ lobular mass connected to $8 \times 6.5 \times 3 \mathrm{~cm}$ uterus with $9.5 \mathrm{~cm}$ long tuba uterina (Figure 3). Gross sectioning through the tumor revealed a white-tan cut surface with a solid, myxoid and lobulated appearance due to irregular intersecting fibrous bands. Gonads were not identified macroscopically. On the light microscopy, the mass was seen to be composed of finely vascular, loose edematous fibrous tissue that was thought to be the scar formation replacing the neoplasia after chemotherapy (Figure 4). It also contained

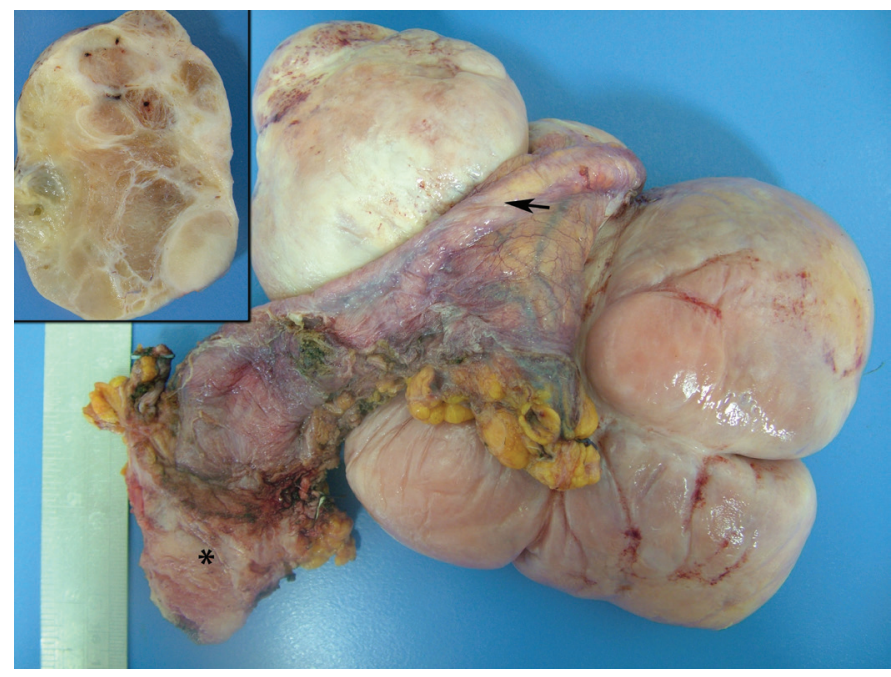

Figure 3. Case 2. Removed surgical material consisting of a large lobular mass, a tuba uterina (indicated by arrow) and uterus (indicated by asterisk). Inset shows the cut surface of the tumor 
scattered seminiferous tubules without identifiable germ cells. There were epididymis and seminal vesicle attached as well. No viable neoplastic element was present. The uterus and its tuba were unremarkable. The dissected lymph nodes were reactive without a metastatic deposit.

Post-operative recovery was uneventful and the patient remained disease free at 43 months follow-up.

\section{Discussion}

Sexual differentiation begins at $7^{\text {th }}$ week in utero under the control of testosterone and MIF. Testosterone is secreted by Leydig cells whereas MIF is secreted by Sertoli cells. Testosterone effects Wolffian structures to form epididymis, vas deferens and seminal vesicles whereas MIF inhibits the default development of female inner genitalia (4). In the case of absent MIF, MIF receptor insensitivity or abnormal MIF secretion timing, Müllerian duct derivatives are observed in phenotypically male individuals. The external genitalia normally develops since testosterone and its activity are not altered (5).

There is a horizontal heritage pattern as PMDS is inherited autosomal recessively. More than one patient within the same family may be affected. Particularly, first degree relatives of PMDS patients should undergo screening particularly if they suffer from undescended testis. Mutations involving chromosome 19 (receptor type 1) and chromosome 12 (receptor type 2) have been reported $(3,6)$.

Undescended testis accompanies PMDS because Müllerian structures block the descent of the testis. Additional genitourinary abnormalities such as hypospadias, penoscrotal transposition, seminal vesicle cysts, renal agenesis, horseshoe

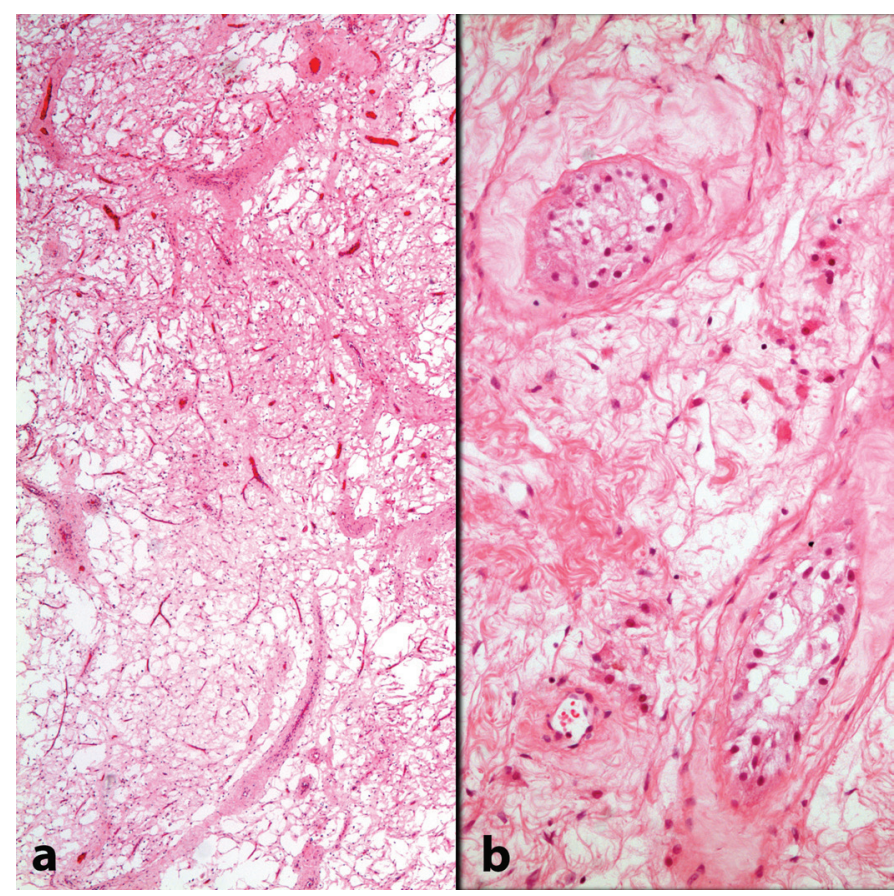

Figure 4. Case 2. The mass was formed by a loose fibrous tissue (panel a) that contained interspersed seminiferous tubules (panel b) (a: hematoxylin and eosin x40; b: hematoxylin and eosin $\times 200$ ) kidney, ureteropelvic junction obstruction have been reported among PMDS patients (7).

PMDS has 3 clinical features:

1. Testes bilaterally undescended and located intraabdominally at ovarian position with respect to uterus (60-70\%),

2. Unilateral undescended testis with an inguinal hernia consisting of testis, uterus and tubes (20-30\%) - described as hernia uteri inguinale,

3. Bilateral testes at the same side and located in the same hernia sac together with the Müllerian structures (10\%) described as transverse testicular ectopia (3).

Apart from the increased risk of malignancy (embryonal carcinoma, seminoma, yolk sac tumor, and teratomas) in undescended testis, Müllerian remnants are also shown to undergo neoplastic transformation. The reported risk of malignant transformation is $2-15 \%$. The most common testicular germ cell tumor is seminoma, which represents $50 \%$ of cases (8). Therefore resection of the bulky remnants is essential in the management of PMDS. Müllerian duct remnants should be removed when possible. Excision diminishes the risk of malignancy and increases the compliance for orchiopexy (9). However, special care for meticulous dissection should be given to preserve vascular supply of the vas deferens, especially in pediatric patients.

Though virilization is not affected in PMDS, most patients are azospermic (10). However, there are a few individuals who have children (3). In accordance with published literature, both of our patients showed male secondary sex characteristics and their semen analysis revealed azospermia.

We observed neoplastic transformation in both cases. This was in the form of intratubular germ cell neoplasia in the first patient and overt seminoma in the second. Management of tumors in PMDS cases should not differ than classical germ cell tumor treatment.

\section{Ethics}

Informed Consent: Consent form was filled out by all participants.

Peer-review: Externally peer-reviewed.

\section{Authorship Contributions}

Surgical and Medical Practices: B.A., M.S.Y., D.E.B., Concept: A.T.B., M.I.D., Ç.A., Design: A.E., M.İ.D., A.T.B., Data Collection or Processing: A.T.B., M.I.D., Ç.A., Analysis or Interpretation: A.T.B., M.I.D., D.E.B., Literature Search: A.T.B., M.I.D., Writing: A.T.B., M.I.D.

Conflict of Interest: No conflict of interest was declared by the authors.

Financial Disclosure: The authors declared that this study received no financial support.

\section{References}

1. Fernandes ET, Hollabaugh RS, Young JA, et al. Persistent müllerian duct syndrome. Urology 1990;36:516-518.

2. Imbeaud S, Belville C, Messika-Zeitoun L, et al. A 27 base-pair deletion of the anti-müllerian type II receptor gene is the most common cause of the persistent müllerian duct syndrome. Hum Mol Genet 1996;5:1269-1277. 
Beksaç et al.

3. Manjunath BG, Shenoy VG, Raj P. Persistent müllerian duct syndrome: How to deal with the müllerian duct remnants - a review. Indian J Surg 2010;72:16-19.

4. Hutson JM, Hasthorpe S, Heyns CF. Anatomical and functional aspects of testicular descent and cryptorchidism. Endocr Rev 1997; 18:259-280.

5. Wuerstle $M$, Lesser $T$, Hurwitz $R$, et al. Persistent mullerian duct syndrome and transverse testicular ectopia: embryology, presentation, and management. J Pediatr Surg 2007;42:2116-2119.

6. Bartlett JE, Lee SM, Mishina Y, et al. Gubernacular development in Müllerian inhibiting substance receptor-deficient mice. BJU Int 2002;89:113-118.
7. Deepika, Kumar A. Persistent mullerian duct syndrome with transverse testicular ectopia: rare entity. J Clin Diagn Res 2014;8:162-163.

8. Chiang $\mathrm{CY}$, Tsai JW, Wang HP, et al. Hernia uterine inguinale and seminoma in persistent Müllerian duct syndrome. Int J Surg Pathol 2010;18:440-442.

9. Wei $\mathrm{CH}$, Wang NL, Ting WH, et al. Excision of Mullerian duct remnant for persistent Mullerian duct syndrome provides favorable short- and mid-term outcomes. J Pediatr Urol 2014;10:929-933.

10. Odi TO, Abdur-Rahman LO, Nasir AA. Persistent Mullerian duct syndrome: a case report and review of the literature. Afr J Paediatr Surg 2010;7:191-193. 